\title{
Skill Development among Youth under Food Processing Training Programmes
}

\author{
Mamta Tiwari $^{1 *}$, Gunjan Sanadya ${ }^{2}$ and Khushboo Gupta ${ }^{2}$ \\ ${ }^{1}$ Directorate of Prioritization, Monitoring and Evaluation, Agriculture University, \\ Kota, Rajasthan, India \\ ${ }^{2}$ (Home Science), KVK, Agriculture University, Kota, Rajasthan, India \\ *Corresponding author
}

Ke y w or d s
Food processing,
Skill
development,
Self-employment,
Empowerment.
Article Info
Accepted:
21 June 2017
Available Online:
10 August 2017

Training is an essential aspect of development of any skill in individuals. The present endeavour was designed to assess the skill development among trainees participated in the training related to food processing rendered by KVK, Kota under RKVY (Rashtriya Krishi Vikas Yogana), Agriculture University, Kota. The objectives were to identify the quality of training programmes and skill development among trainees. A total sample of 125 trainees was selected through random sampling for 5 training programme (25 sample each training). The trainings were provided through lectures as well as practical demonstration on various food processing and preservation techniques. Result indicated that trainings were considered very useful in income generation and self-employment. Training programmes were considered highly qualitative by most of the trainees as $88.8 \%$ marked very good to the quality of food processing training programme. It can be concluded that through skill development in processing of different produce, not only inculcated skills among trainees but it also made them confident, skilled, experienced and gave them opportunities of income generation through self-employment and empowerment.

\section{Introduction}

Training is an important aspect for development of skills among individuals. In recent years skill development comes in limelight due to the unprecedented shortage of skilled man power across the clusters. (Kapila, 2015).

Food processing sector of India is no exception. India is a farm based country where more than $50 \%$ population engage in farming for their livelihood.
In our country due to different climatic condition farmers produce different types of crops according to the season (Rabi, Kharif and Jayad) and then sell them in Govt. mandies.

Most of the farmers don't have knowledge regarding processing, preservation and value addition of their produced grains/legumes, vegetable and fruits. Hence, there is a dire need to inculcate food processing skills 
among those youth who residing in rural/urban India, through different food processing related training programmes.

Training may be defined as an act of inducing the skills or increasing the knowledge and skills of a person for doing a good job (Meena et al., 2012). It is a process that includes a sequence of experiences, a series of opportunities to learn, in which trainees are exposed to certain material/things or events in more or less systematic way. Soybean, Rice, Garlic, Coriander, Amla and Orange are the main crops of Haroti region of Rajasthan. Processing of these crops may enhance their value as well as their shelf life (Tiwari et al., 2016). Apart from these, the processed product might be available round the year and one can be benefited from these products.

Knowledge of food processing and value addition, packaging and labelling, FSSAI regulations and food licensing; trade mark, SWOT analysis, market study, food safety, different schemes of NABARD, DST, DIC, $\mathrm{RFC}$, etc. and cost benefit ratio is very important for new start-up.

With the help of training, food processing skills can be inculcated in youth and they can start their own enterprise and can help in enhancing the GDP of our Nation. For skill development among youth and their selfempowerment, various training programme were organized by KVK, Kota of Agriculture University, Kota. Through feedback of ongoing trainings one can identify the lacunas to enhance and enrich the next training session. Hence present study is an effort to assess the extent of skill development among youths through food processing training.

The main objectives include to know the opinion of the trainees regarding quality of training programme (Table 1). And to assess the skill development after demonstrations and practical training. Also To judge the knowledge of food processing through subject covered.

\section{Materials and Methods}

It was a cross sectional trial conducted during February, 2015 to February, 2016. Trainees were selected from Kota, Baran and Bundi area of Rajasthan. Total five training programmes were conducted during this period, each programme was scheduled for 30 days. Twenty five trainees were selected for each training programme thus the total number of sample was 125. Both theory lectures and demonstrations were provided per day to the trainings. At the end of the training structured questionnaire was introduced and knowledge of the participants was judged. Time to time food products were developed by the trainees. Organoleptic properties, i.e., appearance, colour, taste, texture and mouth feel of developed products were assessed which were also the criteria of knowledge assessment of trainees. The data was analysed to assess the actual skill development among trainees.

\section{Results and Discussion}

Skill development was assessed through (i) feedback of the trainees regarding numerous aspects of the training such as availability of equipments, machinery and raw materials; methods and steps of demonstrations; knowledge of subject matter specialist and subjects covered during the training, etc. (ii) Feedback of master trainer with respect to the regularity, sincerity, discipline, involvement, concentration and learning of the trainees during the training programme.

The quality of food processing trainings was found very effective by most of the trainees as $88.8 \%$ graded it in very good category. The dedication of staff, quality of material used in 
training, knowledge of master trainer and subject matter specialist was highly acceptable. Participants felt that their level of confidence and work efficiency had enhanced during the training.

Table 2 reveals the availability of equipments to conduct trainings, since the food processing laboratory is well equipped with garlic peeler, ginger peeler, mixer, amla juicer, dehydrator, oven, packaging machine, scaling machine, soya milk and paneer making plant, etc., therefore $74.4 \%$ were satisfied with equipments and machineries.

More than $25 \%$ felt that although laboratory was equipped with machineries but they were not confident to use it.

More than $80 \%$ trainees like the methods and steps of demonstration in training. Only $19.2 \%$ marked it satisfactory (Table 3 ).

Table.1 Opinion of trainees regarding quality of food processing training

\begin{tabular}{|c|c|c|}
\multicolumn{3}{|c|}{$\mathrm{n}=125$} \\
\hline Categories & Frequency & Percentage \\
\hline Very good & 111 & 88.8 \\
\hline Good & 10 & 8.0 \\
\hline Average & 4 & 3.2 \\
\hline
\end{tabular}

Table.2 Availability of equipments, machineries and furniture in food processing lab

\begin{tabular}{|c|c|c|}
\multicolumn{2}{|c|}{$\mathrm{n}=125$} \\
\hline Categories & Frequency & Percentage \\
\hline Yes & 93 & 74.4 \\
\hline No & 32 & 25.6 \\
\hline
\end{tabular}

Table.3 Methods and steps of demonstrations and practical training

$\mathrm{n}=125$

\begin{tabular}{|c|c|c|}
\hline Categories & Frequency & Percentage \\
\hline Good & 101 & 80.8 \\
\hline Satisfactory & 24 & 19.2 \\
\hline Poor & - & - \\
\hline
\end{tabular}

Table.4 Master Trainer's knowledge/ skills/ confidence throughout training $\mathrm{n}=125$

\begin{tabular}{|c|c|c|}
\hline Categories & Frequency & Percentage \\
\hline Very good & 99 & 79.2 \\
\hline Good & 23 & 18.4 \\
\hline Average & 3 & 2.4 \\
\hline
\end{tabular}

Table.5 Impact of training through subject covered during training

\begin{tabular}{|c|c|c|}
\hline \multicolumn{2}{|c|}{$\mathrm{n}=125$} \\
\hline Categories & Frequency & Percentage \\
\hline Appropriate & 98 & 78.4 \\
\hline Little appropriate & 23 & 18.4 \\
\hline Not appropriate & 4 & 3.2 \\
\hline
\end{tabular}


They said that the skill development program was systematically arranged, ingredients were available and preparations by the master trainers were very appropriate.

Only $2.4 \%$ participants felt that trainers should be more confident in delivering their skills. Nearly $80 \%$ trainees marked very good to the knowledge of master trainers as illustrated in table 4 . They said that trainers were confident and had appropriate skills for training. Most of the trainees said that they get enough confidence, knowledge and skills for starting a new business due to the knowledge and skills of master trainer.

Table 5 indicate that around $80 \%$ trainees believed that they have attained the prerequisites of a startup, such as- knowledge of financing bodies, government schemes related to subsidies for opening new food processing unit, various preservation techniques and development of soy products, fruit squashes, jam, jelly, pickles, chutneys, vatis, murrabas, dehydrated powders and many more.

Training involves the facilitation of learning by people who can benefit by attaining new knowledge, skills and attitude (Kapila, 2015). In this respect Asif (2000) stated that training must focus on the real needs of the individuals.

Another study indicated that vocational education and skill development can play an important role for rural people by improving household productivity, income, earning opportunity, employability, etc. These activities may also promote food security and sustainable rural development.

Skill development training was considered very useful by the participants for income generation through self-empowerment. It empowered them in confidence building, skills of numerous techniques of food preservation, processing and packaging as well as generated selfemployment opportunities for them which could be a great factor in their socio-economic upliftment. The training was well organised, sequential and liked by the participants. Training curriculum was designed in such a manner that trainees not only learned the skills but also achieved an efficiency level.

All the trainees showed their active involvement during the training, gain new knowledge \& skills which can open new doors to them to upgrade their quality of life in all aspects. These training programmes were tailor made and were based on the needs of the residents and farmers of Haroti region.

Such programmes should be conducted regularly to improve employability and socioeconomic standard of the youth. These programmes will help in economic growth of the country by enhancing the GDP through reducing the losses in agriculture sector.

\section{References}

Asif N. Utilization of vocational training Sialkot region. An impact study of NRSP-Sialkot. NRSP Monitoring Assessment and Planning Section. 2000.

Kapila P. Impact assessment of skill development programme for rural women in district Ludhiana. Journal of Krishi Vigyan, 2015; 3(Special Issue):55-58.

Meena MS, Singh R, Meena HR, Meena BK. Impact assessment of training on food processing and preservation. Indian Journal of Social Research. 2012; 53(2):117-122.

Tiwari M, Singh DK, Tripathi NN, Singh M. Postharvest management and food processing. New Delhi: Himanshu Publications. 2016.

\section{How to cite this article:}

Mamta Tiwari, Gunjan Sanadya and Khushboo Gupta. 2017. Skill Development among Youth under Food Processing Training Programmes. Int.J.Curr.Microbiol.App.Sci. 6(8): 2607-2610. doi: https://doi.org/10.20546/ijcmas.2017.608.309 